\title{
HuMANITIES
}

\section{We Tragically Quipped}

\author{
Marisa Webster \\ Dalhousie Medicine, Class of 2015 \\ 2013 Cynthia Davis Writing Award Winning Submission
}

\begin{abstract}
"Life is short, art long, opportunity fleeting, experiences treacherous, judgment difficult." --Hippocrates
\end{abstract}

Lena Duncan is lying on the operating table. Her chest is split open; the rib spreader anchors her in place. Her undergarments are in a zip-lock bag near the computer, along with a five-dollar bill she had tucked into her sock. Canvas straps secure her legs and outstretched arms into a horizontal ' $T$ '; fluids from the IV tubes race along the blue venous track towards her heart. In the tangled heap of lines, she looks like a collapsed telephone pole, toppled and defeated, engulfed by the squall of activity in the OR.

"We're losing her," Dr. Turcott says, his voice softened by his surgeon's mask. "More suction, Sadie."

I position my hand inside her chest, listening for the greedy slurp of the Yankauer sucker. Seconds later Dr. Turcott's gloved hand is on top of mine. He's shaking his head no.

"Folks, I think we may have hit a brick wall here," he says, stepping back from the table, folding his hands across the front of his blood-spattered gown, a Jackson Pollock of red on blue. "Oh, now wait, Lena's already got that one covered."

It is Saturday, 9 a.m., the day Lena is admitted to hospital. I'm already on my third cup of coffee, and I'm pretty sure that I've seen more patients in the last 24 hours than I did in my entire first year of medical school. Each time I look at a chart I feel like I've met the patient before.

"Susan MacDougall-I thought you fixed her?" I flip through pages of vitals with a haze of nostalgia, each patient fuzzy and forgettable, like a second cousin's absence from a family reunion BBQ. "Small bowel obstruction from Sidney Mines?"
"That was Cindy MacDonald," says Dr. Turcott. We're sitting side-by-side at the nursing station in the emergency department. We're on call, a caffeine-fuelledsleep-when-you-can ordeal that happens every Tuesday and every fifth weekend. We were in the OR until 2 a.m. for an emergency laproscopic cholecystecomy or "lap chole", as I'd been told to call it. Dinner was the usual ham sandwich, pecked at between surgical consults, on white bread, with mayonnaise on the side. I devoured five chocolate chip cookies to keep my energy up, and by 4 a.m. hunger was indistinguishable from nausea.

"Hello?" says Dr. Turcott answering his cell phone.

His ring tone is unmistakeable, - Another One Bites the Dust-which for a surgeon strikes me as a rather misguided incongruity. "What about something with a little more, I don't know, pick me up?" I once asked. He was chewing, half a muffin crammed in his mouth. “Like Stayin' Alive?" Dr. Turcott shrugged, gestured at my bagel, crumbs stuck to his greedy paws. "You want that?" he said, clearly prioritizing breakfast over best impressions. "I'll let you scrub in."

"I know. I'm sorry," he says, into the receiver.

Eavesdropping, I scribble meaninglessly in my notebook: Rocky-Davis incision, sodium, subcuticular, DeBakey, submarine. This is my ill-executed attempt at espionage. A nurse breezes by with a rainbow of urine dipsticks. It's his daughter, I'm sure of it. She had a ballet recital, and he missed it when the lap chole presented to emerg. Last night at the nursing station we laughed, uneasily, while he shouted at his wife over the phone: "Just tell her that Daddy knows she's going to be the best goddamn tea cup that anyone has ever seen!" One of the nurses leaned towards me and whispered, "Just be grateful you weren't here for the whole Little Bo Peep debacle."

"I knew you could do it. I'm proud, honey. Yes, I'm very proud."

Dr. Turcott taps the phone with his index finger. Those hands! Surely kids had to be some sort of liability. I'd 
once watched my cousin light his eyebrows on fire in an over-zealous effort to blow out four birthday candles. Kids-they are wild, frantic and frenzied. Like drunks, but shorter.

"Oh, did she? Well, you can tell Mommy that she needs to start working with Daddy. It takes two to tango."

I met his wife once outside the grocery store. I recognized her from the photograph in his office: the white ruffles of her bikini top looked like two dollops of cool-whip; the freckles on her shoulders, a light dusting of cinnamon. She was a ready-made dessert. "Oh, so you're the student Brent's been helping," she said, smiling fiercely, her tone sugar-coated venom. "I didn't realize you were still around. He hasn't mentioned you in, oh, I don't know-weeks". Dr. Turcott always said he liked his women the way he liked his grapefruit: pink, soft, and fleshy with a hint of tartness. "That's funny," I replied smiling, maybe too enthusiastically, a little demented, "I was just going to say the same thing about you."

I can hear a muffled voice on the other end of the phone.

"No, honey, tango-with a 'T'. Never mind. No, no it doesn't matter. And yes, it is cold out. I'll wear my puffy jacket too. Love you. Tell Mommy I love her too."

Dr. Turcott hangs up the phone. I am fixated on my notebook: Pork chop, somersault, Kelly clamps. He leans back in his chair, rakes his hands through his hair, and, then, slams his fist down on the desk. A Kleenex floats to the floor like a white flag of surrender.

"I’ve messed up again, Sadie."

Lena is positioned in the centre of the sterile field. Overhead, the ceiling-mounted surgical light illuminates Dr. Turcott like a spotlight. Who does this guy think he is, some kind of comedian?

"We had this patient once," the circulating nurse chimes in, "terrible COPD. Oxygen, meds, you name it. In and out of the ICU, but refused to quit smoking. I don't doubt there were other...issues...going on too, and his poor wife had to do just about everything for him. Like his mother or something, just as time-consuming and terrible."
I scour the OR, my sucker still gulping blood. Uh, hello? Has everyone forgotten that we've got an-almost-deadgirl lying cracked open on the table?

"Supposedly, she got so fed up that one night she stabbed him with just about everything she could find: knives, scissors, knitting needles-a meat thermometer even. I imagine the house was a bloody mess. She dumped the body in some snow bank in the middle of nowhere."

There is stunned silence in the room.

"And?"

"He quit smoking. Cold turkey." . .

In emerg I try many tactics to stay awake: crosswords, chocolate, lists, cell phone bingo, coffee, energy drinks. My pre-clerkship training had not prepared me for the marathon of surgical call, like last night when I needed to drive the camera for the lap chole.

"Centre the camera, Sadie," Dr. Turcott moaned, exasperated.

Disoriented, I cocked the camera from side to side. A gallbladder, fiery and inflamed, zoomed across the screen like a comet.

\section{"Left, Sadie. Left. No, your other left!"}

Before the surgery, I had poured half a cup of energy drink into my coffee and microwaved it. It tasted better than I'd expected, murky and sweet, but I'd started to worry that the irradiated caffeine-concoction would somehow trigger cancer or Lupus. I'd tossed the rest down the sink.

Dr. Turcott has just finished talking to one of the emerg docs. He slumps down in the chair and sighs, a gusty decrescendo rumble.

"When we're done here with F-squared, we've got another patient to see. Lena Duncan, chest pain," he says, yawning. "Room 12, maybe. I don't even think it's surgical."

I'd been jotting down all of the death euphemisms I could think of: 15 minutes of flame; a real dead beat; Adios Park; answer the last call; basting the formaldehyde turkey; Bob's Used Coffin Lots; a trip down to the coffineteria; cooking for the Kennedys; dead as a 
dodo; Davey Jones' Locker; no longer eligible for the census; moved into upper management; metabolically challenged; living-impaired; bought a pine condo-I liked that one, especially. The list is in a small grey notebook, mostly used for lab values and to-do lists, which I stuff in the pocket of my scrubs along with my phone, two black pens, and a granola bar. My notes are never written in blue, as per Dr. Turcott's request. Or purple. And if I write them in pink, well, I may as well march myself over to the dermatology unit and join the pimple parade. His words, not mine.

"Well, she's toast," says Dr. Turcott, scrolling through F-squared's lab results. I make a mental note to add that one to my list.

F-squared, short for 'Festering Foot', as nicknamed by Dr. Turcott, was referred to us because of a "foot infection." She needed a surgical consult for what would, likely, result in a debridement or worst-case scenario, an amputation. F-squared was either nuts, depressed, or on drugs. I was sure of it. When I asked her if she noticed any pain, bleeding or odours she just shrugged and stared absently at the jar of tongue depressors. "I guess, not really."

There was an ulcer on her foot the diameter of a baseball. It was necrotic and gangrenous, the texture of raspberry jam mixed with tar. Her foot smelled rancid and ripe, discernible before I entered the room. How is this even possible, I thought, perplexed, in this day and age?

I prodded: "Do you live alone?"

"I live on Sterling Road."

"Are you married?" I scanned her fingers for a wedding ring. "Or partnered?"

We were in one of the patient "rooms", with walls made of flimsy fabric curtains. I could see Dr. Turcott and a nurse, laughing at the end of the hall. Under the fluorescent lights his skin looked thin and pale like a piece of phyllo pastry, stretched tenuously and pulled taut. I noticed once that his eyes were greenspinach green, maybe? - and started thinking about spanakopita. I was terribly hungry.

"Have you ever tried that deli down on the corner of Sterling and Main? They make the best sauerkraut," F-squared asked, readjusting the pillow under her head. Her hair was barbed and untamed; a gelled spike rocketed up towards outer space. It was a hairdo that gave the proverbial 'F-You!' to gravity.

"Then those dark-skinned folks moved in next door. That's got to affect business, don't you think?"

The nurse reached over, coiling her fingers around Dr. Turcott's wrist. Her skin was smooth and creamy like almond butter. She looked at his watch, quickly and indifferently, letting her hand linger. Her fingers slithered across his forearm, parting the delicate blond fuzz, each hair bursting like a blade of grass from a small dirt-patch of freckle. A clock was mounted on the wall in front of them.

I turned my attention back to F-squared.

"Ma'am," I said, looking over the triage notes. "Your sugars are 37 . Through the roof. Are you taking your diabetes medications?"

Her eyes skipped over me, like bare feet on hot coals.

"Are you a doctor?" she demanded, ignoring my questions. "When do I get to see a real doctor?"

"Soon. I just need to get some information from you. Your medications. Have you-

"I'm thirsty."

I could hear the clack of her gums. She was dry.

"I want water."

"I'll find you some. Please be patient for another couple of minutes. Have you ever noticed any.... problems... with your foot?"

She rolled onto her side, now facing me on the gurney. The skin under her eyes sagged, forming two deep pockets that could be used to collect tears. Her wallet was tossed onto a nearby chair, along with a water bottle from some kind of '-a-thon' back in 2007. Tiny silver birds dangled from her pierced ears. Did they nest at night in those fleshy pouches? I was convinced that, somewhere, she had a tattoo of a rose inscribed with something like 'Forever Gary' or 'R.I.P. Dwayne.' I hadn't found it yet.

"Well, of course, dear," she frowned, scrunching up her forehead unsympathetically. "The damn thing is rotten. Can't you see that?" 
In the hallway, Dr. Turcott tapped his watch, looking at me, impatiently.

"If you aren't a doctor," F-squared screeched, "then make yourself useful." Spitting razors, she continued: "And get me some water...Nurse!"

Nurse. Yes, Ma'am, right away, of course.

We are at the nurses' station reviewing the case. A woman is escorted towards Room 12. She is hunched over, stiff and gloomy. It must be Lena Duncan.

"So, tell me about F-squared," Dr. Turcott asks, crossing his arms, legs and ankles, folding himself into a licorice twist. "What's the problem?"

"Well, I think that whole rotten foot thing might be a problem." I giggle-probably, a mistake. "The gaping hole kind of catches the eye."

Dr. Turcott ignores the sarcasm that burglarizes our conversation; silently, he reviews her lab results again. Peering over his shoulder I try to navigate the numbers that chart the coordinates of this woman's future. Like an astrological forecast, the particulars seem vague, ambiguous.

"See," he says, pointing to the computer screen. "Her kidneys are shutting down. She could be dead in, like, 3 months."

I lean forward and squint, hoping that my lack of understanding will simply be mistaken for a lack of visual acuity.

"Yes," I reply, waving my hand at everything but nothing in particular on the screen. "I think I see what you're talking about."

A blond curl has, somehow, liberated itself from beneath Dr. Turcott's surgeon's cap. He is quick to put it back in its place.

\section{"Do you? Or are you just saying that?"}

My head bobs vigorously, and I hope that my body language will convince him that not only do I see-but know - what I'm talking about. Despite my charade of cool collectedness, I can feel the roar of humiliation surge through my body; its arterial heat pulsates under my skin. With my hand, I try to hide the blotchy stain of embarrassment on my cheek.
"Why don't you just point to something-anythingand tell me what it is."

I stand mute, betrayed by my body. I bury my hands in my pockets, trying to soak up the sweat from my palms. My mind is a deserted museum, emptied of all precious medical artifacts. I fixate on a small crack in the floorboard and pray for a tectonic shift to swallow me whole.

"Then you can go see Lena Duncan. I'll deal with F-Squared."

"Well," I stall, pretending to have misplaced something important, first in my pocket, then on the desk, and then somewhere on the ceiling.

"I don't have all day."

I smile stupidly, sharp as a pool noodle: "Well, this has turned into a sadly blunderous teaching moment, hasn't it?"

Forfeiting my half-eaten chocolate chip cookie, I scurry to Room 12.

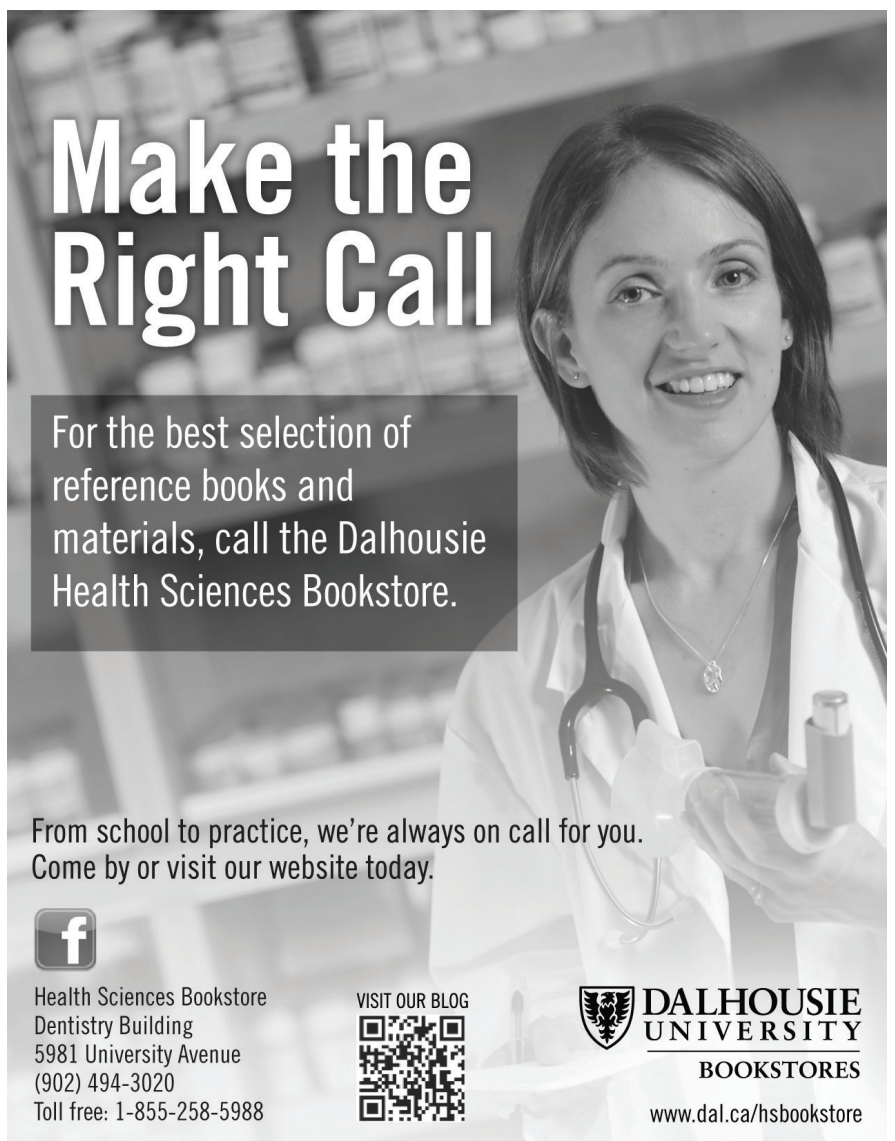


We are told that Lena Duncan's parents are waiting outside the OR. I've been asked to step out and update the family. The prognosis, I must say, is poor. I gather up her belongings to transfer to her family. As I jam the five-dollar bill in my pocket, I realize that, somehow, I've gotten Lena's blood on it. I take it with me anyways. I'm still convinced that all hope is not lost.

Outside in the waiting area, Lena's mother is wearing green sweatpants and a yellow cardigan. She is a dandelion, wilted and inert, drooping in the chair next to Lena's father. He smells of perspiration and wet galoshes.

"I didn't want to waste any time," he explained, pointing to his rubber boots. "I dropped the shovel and hopped in the car."

Her mother, suddenly alert, jolted back to life: "Are you the doctor? How is she?"

"Oh no," I interject, waving my hands, as if signalling them to stop, alerting them of danger, like a washed-out bridge, mudslide, or landmine ahead. "I'm just the medical student." I hand them the bag of underwear. "We're still working on her."

"And? She's going to make it? Please, tell me she's going to make it."

A motley crew of emotions is churning inside me. Dr. Turcott thinks that Lena is dying, I know this much. In some sense, I'd seen death before: as a decapitated head, a lone arm, an open abdominal cavity, in clear plastic bags in the anatomy lab. I am grasping for something to hold on to.

"All hope is not lost," I declare, resolutely, holding out my hand, an act of reconciliation gone astray. Her parents just stand there, blinking and bleak. "Here," I announce, reaching into my pocket, fishing out the blood-soaked bill. I thrust the crumpled wad toward them, holding it out like a peace offering. I want them to know that I'd never steal from their daughter-anear-dead-daughter, to boot. "I'm sorry," I say, wiping the bill against the leg of my scrubs. "There's blood on it," I continue, forsaking all common sense.

Lena Duncan is seated on the exam table in Room 12. She is petite, maybe five-foot two, and her sneakered feet hover in mid-air. She is wearing the johnny shirt backwards and clutches it tight across her chest. Her hair is ombre-the celebrity-dip-dyed-two-tonedlook-seared at the roots with the ends flowing like golden molasses. If I'd learned anything from Glamour, it was that this girl had A-List hair. And that sheer pants are always a no no.

"It's my chest," she says. "It's been bothering me for, like, 4 or 5 days."

Her painted nails remind me of candy caramels; she looks wholesome and sweet.

"Sure. I just want to get a few details first. Lena, how old are you?"

"Twenty-seven. I went to my GP, my orthopedic surgeon, and I was here yesterday. I saw some blond doctor. Kirby? Kurdy? I don't remember."

Her voice is soft and hurried.

"Any shortness of breath?"

"No. But it hurts right here," she says, rubbing her hand over her chest. "In my neck, too."

I continue with my history and physical exam. Blood pressure is normal, good even, at 110/76. Although the chest pain is worse with movement, there is no back pain, neurological deficits, or hoarseness. She is a non-smoker. Aside from the tenderness, her cardiovascular exam seems normal. I'm stumped.

"Lena, you mentioned seeing an orthopedic surgeon. What for?"

She blushes, uncomfortably. "I busted my shoulder a while back. 6 or 7 weeks maybe."

"How'd that happen?"

"It was stupid. I got in a fight with my girlfriend. I lost control on black ice and crashed my car. Brick wall."

I fumble through her old charts. In my haste to flee Dr. Turcott I'd neglected to review them.

"It says here that you were drinking?"

"Yeah, that probably didn't help either. They kept me overnight and discharged me home the next day. I had to follow up with my GP. And I did. Everything was fine. They X-rayed me and everything." She fidgets with the paper that covers the exam table, pinching 
it into triangles, erecting a village of miniature tepees alongside her thighs.

Dr. Turcott pokes his head in the room.

"Well, hello there. Lena? Dr.Turcott. I see you've met my young colleague." He extends his hand, pumping hers vigorously. "I'm going to have a chat with Sadie in a bit, but from what I've heard from the other docs, it sounds to me like you're still experiencing some muscle pain from the accident."

Lena smiles, the corners of her mouth upturned like a cherry canoe. Her blush has intensified, bursts of crimson bubbles spattered across her cheeks. Palms down, she sweeps her hands back and forth across the examining table, bulldozing her paper village.

"Mistakes," I say, ruminating aloud. My thoughts straddle the line between empathy and disapproval for Lena. I had gotten caught once, cheating on a high school biology exam. I'd written the answers on a piece of masking tape, which I'd stuck to the underside of my uniform. During the exam, I rolled up the hem of my plaid skirt unveiling the words 'Domain, Kingdom, Phylum, Class' - a taxonomic tartan at my fingertips. Fortunately, I was only suspended. "I guess they happen to the best of us."

Lena settles back against the wall. Her expression oscillates between relieved and demoralized. "Thanks," she says, not entirely convinced by my sincerity. "The worst of it was losing my licence. Now I have to ride in the backseat of my parents' minivan."

"They obviously care," I say, folding my arms across my chest. "To chauffeur you around like that."

"We stopped for icecream," she says, mirroring my mannerism. "On the way home from court. My mom cried the whole time."

Dr. Turcott, quietly reviewing my consult notes, springboards back into the conversation. "Well," he says, drumming his fingers on the Mayo stand. Reflected on the stainless steel surface, his hand looks like a five-tentacled squid, fleshy and pulsating. "I'm pretty confident that a surgical consult was overkill here, and I'm sorry the emerg docs kept you waiting for me. Sadie and I are going to step outside to review things, but it sounds to be like a bad case of misbehaving musclelitis." $\mathrm{He}$ chuckles a little. "You probably just tweaked something. We'll get you all fixed up."
One hour later, we send her home with an anti-inflammatory-and pep talk-to help ease her pain.

We are in the surgeon's lounge, bums barnacled to the couch. Tennis plays on the wall-mounted TV. There've been no new consults for the last few hours, which means there is a good chance that we can leave the hospital, for now.

"So Miss Sadie, you still think surgery is your thing?" Dr. Turcott asks.

I shrug, preoccupied by the television screen. As a third-year medical student, I'm often encouraged to consider radiology. Or marry a radiologist. Either, or both, whichever makes me happier. I'm told that, at the very least, I should try to specialize in one of the ERODE specialties-Emergency, Radiology, Ophthalmology, Dermatology or ENT-lifestyle specialities known for the big bucks, decent call schedule, and liveable hours. It is almost like working a normal 9-to-5 job, except for the ever-constant fear of getting sued, or worse, killing someone, or worst of all, killing someone and getting sued. Sometimes pathology falls into the mix, putting the "P" in the now "E-ROPED" specialities. Of course, pathology does have its drawbacks: patient contact often involves a bone saw, and conversation is at its most minimal, but heck, if you can hack it, it's not a bad way to make a living.

"The lifestyle is crummy. But I kind of like the simplicity of surgery, y'know?"

"Simplicity?" he says, his tone now teenaged and haughty. "You think this is easy?"

"No," I stammer, eager to redeem myself, "I just mean, if you let it simmer long enough, every surgical consult can be boiled down, reduced to the same old question: to operate, or not to operate?" It was vaguely Shakespearean, which seemed like a good enough reason as any.

“To operate, or not to operate?" he echoes. "Tarantino?"

"Ummm, no," I say, scratching my head, not entirely sure how we'd skidded off track so soon. "I can't watch those movies. The violence. But I did dress up as Uma Thurman once for Halloween."

“Oh, as Mia Wallace?" 
"Who?"

"Mia Wallace? Uma Thurman played her in Pulp Fiction. The Tarantino flick?"

"Oh. No," I say, feeling somewhat abandoned, left behind in the dust of our conversation. "Just Uma Thurman."

“Oh," Dr. Turcott says, disappointed. "You would have made a good Mia Wallace."

Hoping to pull a U-Turn, I untuck my shirt, lifting it up an inch or two.

"Want to see something?"

Without giving him a chance to respond, I undo the drawstring and roll down the top of my pants, revealing the inky wisdom tattooed on my hipbone. It says: 'When it is dark enough you can see the stares'.

\section{"Emerson."}

My boyfriend had bartered a deal: $40 \%$ off in exchange for his Led Zeppelin record collection. Zane, the tattoo artist, worked fast, furiously, and flushed.

"I was fifteen," I explain, quickly pulling up my pants, concealing the tattoo in the cotton bunker of my scrubs. "I always assumed that he was just really excited about those records." Naiveté is a funny thing — a virtual black hole of critical thinking and common sense. "Turns out he was a speed addict, or something."

Dr. Turcott is fixated on me with an expression that could have been either puzzlement or pity. I suspected it was both.

"Stars," I clarify, my eyes widening, now rounded and bulging, causing my eyebrows to levitate skyward. It was a look that was probably mistaken for surprise, an electric shock, or gas.

Dr. Turcott is laughing so hard that he smacks his head against the wall. There is the faint, fatefully timed, applause from Wimbledon.

"Stars," I repeat, lowering my voice, hushed, a little paranoid. "Not stares. It's a spelling mistake. A typo. I know my Emerson."

"That is the most ridiculous thing I've ever seen."
“Tell that to Tarantino," I say, giving Dr. Turcott's shoulder a playful tap with the back of my hand. "You know, only five other people have seen this thing: My roommate, three exes, and my family doctor. Okay, and maybe a cab driver."

"Really?" he says, massaging the back of his scalp in amusement. "Why me?"

I feel startlingly disarmed-just hypoglycemia, I hope. I fumble for my granola bar in the pocket of my scrubs. The "Thwock, thwock, thwock" of the tennis match is rhythmic and hypnotizing. It is a feeling that needs to be ignored.

"I don't know," I say, staring absently at the TV screen. Out of the corner of my eye, I can see him smiling, trying to coax an answer out of me. "I guess, I just-

Dr. Turcott raises his index finger, signalling me to pause. "Yes, hello?" he says, answering his cell phone, no longer concerned with my wisdom or with me. "You're kidding. She's here? Now?" I try to make out the voice on the other end. "Dammit. Yeah, I'll be right down."

Dr. Turcott stands up, snatching his surgeon's cap off the coffee table. In his rush, he knocks over my Styrofoam cup filled with water.

"Get up," he says, burying his curls under his cap. "It's Lena Duncan."

"Really? What happened?"

"Her aorta. It ruptured."

I grab a blue mesh cap and slip a pair of matching OR booties over my running shoes. "Are you sure?"

"We're going to the OR. Now."

"We missed it?"

"Stop talking," he says. "You're scrubbing in."

During the surgery, a small arterial geyser erupts from Lena's chest cavity-blood streams down Dr. Turcott's cheek. There's violence to the red and white zebra print that looks like slashes, claw marks, on his face. I wonder if this is how the meat thermometer guy looked. 
"C'mon, Sadie. Follow me with the suction." With his shoulder, he gestures towards his face. "Can someone get this?"

The circulating nurse hurries over and dabs the blood with a towel: "Would you like me to call in someone more...experienced... to replace the medical student?"

I push my sucker deeper into Lena's chest cavity, imagining duct tape over the nurse's mouth.

Dr. Turcott had bought me dinner, once, after I mixed up the medication orders for two of his post-ops. The nurse had caught it, pulled him aside, whispered, and wagged her finger at me. "Yes, her," she said, wrinkling her nose. "The medical student." The words rolled off her tongue like 'puppy mill' or 'pornography' Dr. Turcott took me by the shoulder and steered me to the surgeons' lounge. With the door closed, he hurled a clipboard against the table, knocking a can of Pepsi into a plate of mashed potatoes. Murky brown streams polluted the peaks and valleys of white fluff. Throughout all of this, an OB/GYN had been napping on the couch. Her eyes popped open and closed,-a quick hello/goodbye-and she covered her head with a pillow. "Is this some kind of joke to you?"

With my back plastered against the wall I blinked, maniacally, squinting, like I'd rolled out from under some rock and into the sunlight. My eyelashes, wet and salty, combed the air. In the bricolage of emotions, I threw up in the garbage can. That night, we sat at the bar and ate burgers in silence.

"No, she's fine," Dr. Turcott says, with his hand on top of mine, guiding me around the mediastinum. "Like this."

We work quickly, clamping and suturing, weaving and winding, in and out of Lena. Pockets of sweat cause the latex to stick to my skin in polka dots. I should have picked smaller sized gloves.

"Tamponade," says Dr. Turcott, shaking his head, pointing to her heart.

I can see the pericardial sac, ballooned and heavy. Smothered, each beat is now an onerous struggle. Within minutes, the lines on the screen are crimped and erratic, like spikes on a seismograph.

"V-fib," the scrub nurse says to the team. "What do you want to do, Brent?"
Dreariness drifts into the OR like a fog. As the collective gaze orients towards Dr. Turcott, he stops for a moment and rests his hands on top of Lena. He stretches his neck left, and then right, each ear bobbing, his head tilting back and forth like a seesaw.

"Put the sucker down Sadie," he says, his defeat condensed into the droplets of our conversation. "And step back from the table."

"But, Dr. Turcott", I say, gripping the sucker, my gloved hand calcified, rigid. "What ab..."

"Sadie," he repeats, this time more forcefully, his tone a quick slap on the wrist. He motions me to clamp off my sucker.

"Right," I mutter, unkinking the plastic tube, pulling it out of Lena. "Brick wall."

Dr. Turcott and I are in the surgeons' lounge. He decided that it would be best to wash his face and change into a fresh pair of scrubs before talking to Lena's parents. I agree, and do the same, except I can't think of any good reason to wash my face or change my scrubs. But I do it anyways.

"I wonder whose phone number this is?" I say, pointing to the leg of my pants. I'd often seen the surgeons jot down the phone numbers of family members and loved ones to contact post-surgery. Even though the scrubs were laundered, I could sometimes make out the faint tracing of a name or phone number. "Pizza Hut?"

Dr. Turcott is sitting at the table across from me. The dark circles under his eyes are the gentle bruises left by Lena Duncan. He sips the cold dregs of his coffee pausing, absently, with each mouthful. In between swallows, he spins his mug on the table, quick pirouettes across a slick mahogany rink. It is dizzying.

I fidget with the newspaper and watch infomercials on TV. A blonde woman is smiling and sticks a contraption that looks like a small radar gun into her ear. A pink fluffy towel is wrapped around her like a hug. Through the miracle of science, the gun pinpoints the wax and -in one fell swoop-vacuums it off the epithelial carpet of her ear canal.

"Who buys this junk?" I ask, tearing one strip of paper off, then another. Q-tips were my mini-rebellion 
against medicine, even though we'd all been taught to recommend mineral oil instead. "Would you?"

Dr. Turcott is silent, his attention towed by the ceramic vortex. I examine the small blotch of perspiration on his scrubs, like a Rorschach. His sweat stain reminds me of a fire hydrant. I have no idea what this means.

"Dr. Turcott?"

I reach across the table and put the brakes on his mug. It wavers and, then, grinds to a halt. Dr. Turcott does nothing. I am quick to remove my hand.

"Dr. Turcott," I repeat, wiping the crust of mascara out of the corner of my eye. "I have something to ask you."

The wooden frame creaks as he leans back in his chair. He's given up on the mug.

"Do you have any holiday plans, like, around Christmastime?"

Dr. Turcott is watching the smiling woman stick the radar gun into the ear of some kid. I imagine myself stealing the woman's towel and wrapping it around Dr. Turcott's shoulders. His arms are zigzagged across his chest, and he's cradling an elbow in each hand. That woman would probably just stand there, grinning, blissfully armed and naked.

"I was thinking of coming back here. You know, in fourth year. To do a surgical elective-with you."

He shifts his gaze, making eye contact with me for the first time since the OR.

"No." he says, flatly, uncrossing his arms, pulling his chair in towards the table. My heart plummets into the pit of my stomach. His eyes narrow, scrutinizing me. "I mean I don't have any holiday plans."

"Oh, super," I say, making a mental note to never say that phrase aloud again. "I guess we can put that on our to-do list of things to talk about later." I pull the grey notebook out of my scrubs and open it to a fresh page. In black ink I write the number " 1 " in the margin and 'Talk later with Dr. T' next to it. I underline my note, like an idiot. Out of the corner of my eye, I can see Dr. Turcott watching me. I draw a big bulbous loop, as if lassoing my reminder, but then start to worry about the conspicuously sausage-like shape. I slam the notebook shut.
"Of course, I'll have to talk it over with my boyfriend first," I say, cramming the notebook into my pocket. "Logistic-wise."

Dr. Turcott adjusts his scrub cap, undoing and retying the knot. He pulls it towards his eyebrows, masking the fine lines etched into his forehead.

\section{“Dr. Turcott?"}

"What now, Sadie?"

"It happens," I say, lifting my arms, palms up, like I'm balancing two platters. My head is tilted, off-kilter. "It was a mistake."

I imagine Lena's mother trying to buy coffee with the blood-soaked bill. Is that blood? The clerk will say, shaking his head. You can pay with debit, VISA, MasterCard, and now, coffee club cards, he'll explain, pointing to the sign on the counter. But not with that. Oh, and unfortunately, we don't take American Express either. With a smirk, he'll yammer away, wearing his headset like an air traffic controller, pretending that on some level, his job really matters. Would you like to start a coffee club card, ma'am?

"I gave Lena's mother the five-dollar bill," I confess, rolling the newspaper under my fingers. "It had blood on it."

Dr. Turcott leans forward and props his elbows on the table. He slides his fingers around the back of his neck, clasping his fingers. "Can you stop talking?" he says, punctuating our staccato conversation. "Please."

"Oh," I mumble, hanging my head. "I'm sorry. Really."

I sweep the shreds of newspaper into the palm of my hand like a zamboni. The table looks clean and sleek again. "Maybe you should eat," I say, standing, walking towards the kitchenette. "I'm sorry. I thought I saw a microwave burrito."

In the kitchen, a chocolate chip cookie is on the counter. It's soggy, but I eat it, the thick paste enveloping my teeth. It walls off my molars as if they were latent TB. In the other room, Dr. Turcott's cell phone sings. The digital glow of the microwave reads 8 p.m., which means there's a good chance that it's his wife or his daughter calling. I listen for his voice but there is only stillness and, then, a beep: it's gone to voicemail. 
"That's when you know you found somebody special," Dr. Turcott says, appearing from around the corner. There is a squirt of dish soap, the faint waft of lemon, clean and fresh. His mug clinks against the aluminium sink.

"What?" I say, over the whoosh of running water. I don't understand.

"Pulp Fiction," he says, setting his mug in the drying rack. He has one shoulder buttressed against the wall. His arms are folded across his chest. "When you can just shut the F-up for a minute and comfortably enjoy the silence."

"Oh," I say, opening the freezer door, a sudden sting in my cheeks. I watch Dr. Turcott disappear around the corner. "With what's her name, right?"
"Uma Thurman?"

"I was going to say Mia Wallace."

The icy swell of the freezer hits me like a belly flop on the stomach. Two sleepless days of call have zipped by with a time-warp velocity and have, suddenly, crashed into the present. I stand for a while with the door open, staring into the empty, white void. Crossing my forearms, I lay them on the floor of the freezer, resting my forehead on top of them. The deserted chill seeps into my skin. As the cold breath fills my lungs, I remember what I was looking for in the first place.

\title{
Guysborough Antigonish Strait Health Authority
}

\author{
"Working Together For a Healthy Community"
}

\section{GASHA}

Guysborough Antigonish Strait Health Authority serves a population of just under 44,000 residents in Antigonish, Guysborough, Inverness and Richmond counties in picturesque Nova Scotia.

Our District includes five healthcare facilities in Antigonish, Canso, Guysborough, Evanston and Sherbrooke. We also have services relating to Primary Health Care, Continuing Care, Addiction Services, Mental Health, and Public Health. GASHA is home to St. Francis Xavier University, a campus of the Nova Scotia Community College and has the first accredited District Trauma Centre in Nova Scotia.

Living and working in rural Nova Scotia comes with many benefits. Smaller communities mean closer relationships with fellow physicians, staff and local residents while still maintaining close proximity to the major centres within the Province.

GASHA offers a competitive recruitment package and provincial incentives for physicians. We invite you to come and check out our lifestyle. You will not be disappointed.

\section{Contact:}

Dr.Jeremy Hillyard

District Chief of Staff

Guysborough Antigonish Strait Health Authority

(902) 867-4500 ext.4710

Jeremy.Hillyard@gasha.nshealth.ca

www.gasha.nshealth.ca 